\title{
Pricing Strategies - Comparative Analysis of Non-Exporting Enterprises and of Intense Exporters Based on the Example of Polish SMEs
}

\author{
Adam Oleksiuk*
}

The research aim of the paper is to verify the differences with regard to the pricing strategies being implemented among non-exporting enterprises and intense exporters based on the example of Polish SMEs. The study presented was conducted between May - June 2019 on a representative sample of Polish SMEs created after 2004: non-exporters and exporters with a min. 25\% share of exports in the total sales. The research method applied is computer assisted web interviewing (CAWI) and computer assisted telephone interviewing (CATI). The total count of the sample is 240 businesses, randomly selected from a database which contains 2969 Polish companies. The study emphasizes that between exporting companies and non-exporting companies, there are differences in the pricing strategy application. Exporting enterprises more frequently have a differentiated pricing policy. No significant connection between the pricing strategy and the quality strategy was observed, both among non-exporting enterprises and intense exporters.

Keywords: pricing policy, pricing strategies, Polish SMEs, non-exporting enterprises, intense exporters.

\section{Strategie cenowe - analiza porównawcza nieeksportujących przedsiębiorstw i intensywnych eksporterów na przykładzie polskich MŚP}

Celem badawczym artykułu jest zweryfikowanie różnic $w$ zakresie strategii cenowych wdrażanych wśród przedsiębiorstw nieeksportujących i intensywnych eksporterów na przyktadzie polskich MŚP. Prezentowane badanie przeprowadzone w okresie maj-czerwiec 2019 r. na reprezentatywnej próbie polskich MŚP utworzonych po 2004 r.: nieeksportujacych oraz eksporterów o min. $25 \%$ udziale eksportu w całości sprzedaży. Zastosowana metoda badawcza to wywiad przy wykorzystaniu ankiet $w$ internecie (CAWI) oraz wspomagane wywiady telefoniczne (CATI). Łaczna liczebność próby to 240 przedsiębiorstw, wylosowanych z bazy danych liczacej 2969 polskich firm. W artykule podkreślono, że między firmami intensywnymi eksportami i firmami nieeksportujacymi istnieja różnice w stosowaniu strategii cenowej. Intensywni eksporterzy częściej prowadza zróżnicowana politykę cenowa. Nie zaobserwowano istotnego

\footnotetext{
Adam Oleksiuk - dr, Collegium of World Economy, Warsaw School of Economics, Warsaw, Poland, https://orcid.org/0000-0003-1796-8125.

Adres do korespondecji: Collegium of World Economy, Warsaw School of Economics, Warsaw, Poland, Al. Niepodległości 162,02-554 Warsaw, Poland; e-mail: adam.oleksiuk@sgh.waw.pl.
} 
zwiąku między strategia cenowa a strategia jakościowa, zarówno wśród nieeksportujących przedsiębiorstw, jak i intensywnych eksporterów.

Słowa kluczowe: polityka cenowa, strategie cenowe, polskie MŚP, nieeksportujące przedsiębiorstwa, intensywni eksporterzy.

JEL: L11, L15, M10, M16, M31

\section{Introduction}

Price is one of the key elements in the strategy of any enterprise; when it is well configured and adapted to the requirements of consumers and particular markets, it is of critical importance for the company's "prosperity". If price is not determined in accordance with the expectations of the target markets selected, this can have negative implications for product sales, and in consequence for the financial performance. The goal of each enterprise is profit maximization, but to achieve this, all the areas related to the product itself, the costs, and the prices must be properly managed. Hence, a fundamental question arises what pricing strategies are most efficient from the point of view of small and medium-sized enterprises (SMEs). The related literature emphasizes that the correct pricing helps build the relations with clients and improves the usability of the product being consumed by buyers, both on the domestic and foreign markets. Therefore, the pricing policy can be recognized as a fundamental aspect which affects the success of small and medium-sized enterprises. The research aim of the paper is to verify the differences with regard to the pricing strategies being implemented among nonexporting enterprises and intense exporters based on the example of Polish SMEs.

\section{Literature Review}

When defining the notion of a price, it should be emphasized that it is the value of and the payment for a product or service offered by a given company; therefore, price should be described as the amount of money needed for the consumer to obtain the specified usability. This means that clients have, first, different tastes and preferences, secondly, they choose from among products those that maxi- mize their customer satisfaction (Monroe \& Lee, 1999, pp. 207-225). Marginalism leads to a situation where buyers are able to order all the alternatives according to the growing preferences, while buying the most preferred product first. The development of a pricing strategy is an important task in marketing, since prices are its only element which generates sales profits/revenues; other components create only costs. Consumers perceive products depending on the price level. The pricing of products is difficult, mainly because a high price may trigger negative feelings about the products, and a low price may be misleading regarding other characteristics of the products, such as, e.g., the quality. The type of the pricing strategy being implemented by SMEs depends on the goal which the pricing strategy intends to achieve. Therefore, an efficient pricing strategy should reflect a coherent price "structure" which facilitates the achievement of business goals by ensuring a better value of the product/service being offered than the value proposed by competitors (Meehan, Simonetto, Montan, \& Goodin, 2011, pp. 25-41; Dolgui \& Proth, 2010, pp. 101-110). According to Sikora and Baranowska-Prokop, "Polish SMEs demonstrate strong dynamics of export growth. However, the export offer of product portfolio is no different from the domestic market supply. Adjustment of the product offer to the requirements of the foreign customer is rather limited. The pricing strategy of Polish SMEs is grounded on a simple cost-based method with simultaneous comparison to the prices of competitive products" (Sikora \& BaranowskaProkop, 2021). When SMEs prepare their pricing strategies, they must be aware of the existence of different factors that could help them in making price-related decision. The decisions concerning the prices of products and their distribution on international markets are country-specific (Jain, 1989) 
and differ from the decisions being made on the domestic market (Diller \& Bukhari, 1994, pp. 163-170; Monroe \& Lee, 1999, pp. 207-225). Some of born-global SMEs prepare products only for international and export markets, since they understand the fact that the domestic market could be too small and exporting could be a real opportunity to benefit from the economies of scale (Neubert, 2017, pp. 43-44). In such a case, the saturation of the domestic market forces SMEs to look for foreign markets (Kotabe \& Helsen, 2016, pp. 89-90). Such companies aim at foreign expansion in order to minimize and spread the risks and to decrease the dependency on one geographic market. It is worth noticing that the life cycle of a product reaches the maturity stage usually on the domestic market, while on less developed markets the same product is still at earlier stages of this cycle (Hofer, Niehoff-Hoeckner, \& Totzek, 2019, pp. 74-94). It should also be emphasized that all the enterprises deal with international competitors, and not only on export markets but also on domestic ones. Hence, becoming a competitive entity on the international arena is, first, the primary requirement for successful exporters; secondly, this is also the best defense that local companies may use to counteract importing from abroad. Exporting has a positive effect on the economy of a given country not only on the macro scale but also on the micro scale. Exporting offers SMEs a lot of additional possibilities which could not be achieved by these companies in domestic markets. As a result of international operations, production increases, which reduces its costs, and this in turn improves the general profitability of an enterprise. SMEs operating on foreign markets help increase the overall competitiveness, the prestige of businesses less recognized so far, and this leads to an overall expansion of a company, decreases any kind of risks by diversifying the operations (Gherasim \& Gherasim, 2019, pp. 62-67; Hollensen, 2017). Benefiting from the economies of scale distributes the fixed costs of running business operations better, which improves the general return on investment. The authors emphasize that SMEs find new markets for products with declining prospects for domestic sales, which extends the life cycle of a product (Hofer, Niehoff-Hoeckner, \& Totzek, 2019, pp. 74-94; Monroe \& Lee,
1999, pp. 207-225). SMEs have also the option of becoming familiar with, and then implement, any high tech used abroad, and new markets could bring ideas for further innovations (Mansour, 2020). The GDP level is the primary measure of the economic attractiveness of foreign markets. Along with the growing GDP, the demand for goods and services also increases. The income distribution within a particular country is also important in determining the segments and niche markets. It is important to observe not only the current economic situation in a country, but also its future development in terms of the population and population density, inflation, and economic growth, the age and income distribution, urbanization, and other business activities, which will have an effect on the markets and prices. The economic environment of a country influences the price decisions. It substantially influences the costs of a company, determines the demand for a given product/service, and the prices that local clients can afford and are willing to pay (Whitelock \& Pimblett, 1997, pp. 45-66). It is also worth noting that some products are considered first tier in more developed countries, and in more impoverished countries they are perceived as luxurious/second tier articles (Jain, 1989, pp. 70-79).

One of the key price changing factors in global marketing are foreign exchange fluctuations, which often require the pricing policy to be adjusted. Adapting the prices to the current competition in the market may, after all, mean lower margins. A strong domestic currency and growing costs in the country of origin can also force an enterprise to change the sources of supply. When the domestic currency appreciates, the company must precisely examine/trace back all of its costs in order to ensure that it will be able to stay competitive in the target markets. Two pricing options should be taken into account. The first one is determining the prices of products on the domestic target market. In this case, each appreciation or depreciation of the currency in the production country leads to profits/losses for the seller. The second form consists in determining the prices of products in the domestic currency of the home country. If this is the case, each appreciation or depreciation of the domestic currency will cause an increase 
or decrease in the prices for clients, with no direct consequences for the seller. Therefore, in practice, the manufacturer and its distributor could cooperate in order to maintain their share in the international market. Each party, or both parties, could decide to accept a lower profit percentage. In long-term contracts, both parties can agree on a clause concerning the exchange rate, which would make it possible for them to agree supplies and purchases at fixed prices in the domestic currency of each of the companies.

Inflation is a phenomenon common in almost any economy. In this regard, inflation requires temporary adjustments, which are caused by growing costs that must be covered by growing sale prices. A key requirement in determining the prices under inflation conditions is keeping the operational profit margin. According to many authors, it is recommended to use LIFO cost calculation methods at growing prices (Carpenter, Boyle, \& Ren, 2012, pp. 645-650). This method may be used to valuate materials, goods, and products. The inventory measurement methods are important because of the fact that the prices of purchased materials and the overall production costs change in time. It often happens that inventory units stored in a warehouse have been accepted at different prices. When issuing any inventory from its warehouse, a company must decide at what price to account for its issuance. Without detailed inventory records, an enterprise is not able to indicate exactly what part of the inventory has been accepted at what price. It only knows how much of the inventory has been received at a given price (Carpenter, Boyle, \& Ren, 2012, pp. 645-650).

Consumers play a very important role in a company's success. The primary goal of each organization is to satisfy well identified needs of consumers. Enterprises should think of not only their domestic markets. They must think globally but operate locally since in all markets, customers are the driving force of marketing. The products must be distributed by means of the most appropriate channels and measured in accordance with the requirements of the domestic market environment. The domestic market conditions may be different, and companies must adapt to the needs of local clients. Too low prices, although initially attracting clients, will not keep them in the long run, because customers will also look for such products that are available at even lower prices. SMEs must make sure what consumers they want to attract, and then prepare strategies in order to keep them. In addition, when determining the prices, the ability and the readiness of consumers to pay the specified amount for the product must be taken into consideration. A higher price may, e.g., increase the demand for luxurious goods and result in a demand curve with a positive slope. Small and medium-sized enterprises should also recognize the role served by price elasticity of demand in their pricing policy. Understanding price elasticity gives the owners of SMEs an idea of what will happen with the demand with possible changes in the price. It is believed that consumers are less sensitive to prices when the product that the consumers want to buy is unique, or when it is perceived as a prestigious product, as well as when substitutes of the product are relatively difficult to access, and the total expenses of the consumers for the product are low in relation to their income. When determining the prices, SMEs must be also aware of what their competitors are doing. When a product is new on a market, high prices may encourage competitors to enter the market with a similar product, but at a lower price. In the case of already existing products, SMEs must consider the impact of a change in the price on other enterprises. Predicting what a competitor may do as a reaction to a change in our price may help determine the magnitude of the changes being made in the pricing policy. Brassington and Pettitt emphasize that the nature of the industry in which an entity operates may, in general, affect how competitors implement their price strategy (Brassington \& Pettitt, 2013, pp. 265-265). For example, in an oligopoly market, in connection with the fact that the number of vendors offering the given product is small, enterprises quote their products or services relative to their competitors. Acting in such a market, they must determine the number of competitors in their industry and use this knowledge to predict their possible reaction to an increase in prices, and thus provide the company with valuable information on what price to fix.

The distribution channels affect the price fixed by a company. Depending on 
the length of the distribution chain (the number of outlets) within which the products flow, the needs and expectations of the channel's members may differ. Consequently, these must be clearly specified at the very beginning, since each member of such a channel will have their own desired margin, profit level, and expectations regarding the need to cover the costs related to managing and distributing the product (Brassington \& Pettitt, 2013, pp. 262-265). This obviously affects the price fixed for a specific product, since the distribution costs could vary.

An enterprise's pricing policy is also affected by the generally used marketing strategies of the enterprise. Kotabe and Helsen point out that marketing plans should be constantly developed not only to satisfy the identified needs of customers, but also to disclose the ambitions and wishes of an enterprise. Therefore, a clear niche can be created which can be then emphasized by the use of marketing communication elements within allocating resources between BTL and ATL (Kotabe \& Helsen, 2016, p. 397). At the same time, these authors have jointly emphasized an important difference between the organization's goals and the marketing goals, consisting in that the organization focuses more on the company's actions, well-being, security, and „temper”, while marketing goals are more focused on specific target markets and positioning within these markets (Kotabe \& Helsen, 2016, pp. 529-532). The pricing strategy chosen for a specific product should therefore supplement the specific market on which the enterprise wants to operate. The company may have different product categories, each of which serves different consumer segments, which may require a different approach to pricing (Gullstrand, Olofsdotter, \& Thede, 2014). Therefore, the relationship between the price and the quality should be determined, because enterprises often offer higher bonuses for high quality products. The costs are an important factor in determining the price. It is commonly believed that determining the total costs precisely is quite complicated, but also crucial. This is particularly difficult within the short-term perspective, because the price must be specified at a level acceptable for consumers in a competitive and unpredictable environment. For example, although both the fixed and variable costs could be determined with great accuracy, it may be necessary to offer the product at a lower price at the early stages of the product life cycle in order to increase its sales. Therefore, it can be concluded that the shaping of the relationship between the product price and its quality often affects positively, but also negatively, the image of the enterprise. Therefore, many authors suggest that the implementation of a low-price strategy should be considered with great care (Gorodnichenko \& Talavera, 2017). In any case, in-depth marketing studies are necessary for the price to be acceptable to potential buyers; this reduces the risk of unnecessary disappointments on the part of the producer.

Apart from generating revenues, the price plays an important role as a strategic factor in developing competitive advantage on the market. The amount of an enterprise's revenues and its promotion in the scope of positioning, namely finding a proper position in customers' awareness, involves, among others, fixing a proper price. Making decisions on this matter is not an easy task, and is subject to many price factors (Gullstrand, Olofsdotter, \& Thede, 2014). Sufficient/satisfying sales on the internal market, the nature of the product being offered, the regulations regarding the principles and procedures of delivering products, tariff measures, customs charges are the reason for which some enterprises restrict their activities only down to the domestic market, without being active on foreign/export markets. Some enterprises are also afraid that their actions being so far typically ethnocentric will be insufficient and will not be enough on international markets. Still, some companies with transnational ambitions choose global expansion. Therefore, a question arises in the above-mentioned context concerning export pricing strategies.

It is worth pointing out that researchers dealing with international marketing have at their disposal a whole catalog of pricing strategies. The most important purpose of these strategies should be contributing to the achievement of the assumed sales results and profits in the global context. Typical customer-focused strategies such as skimming, penetration strategy (low price strategy), prestigious pricing strategy are often used on international markets (Hol- 
lensen, 2017, pp. 539-541). Global pricing may also rely on specified external criteria such as, e.g., an increase in costs when products are sent at long distances to other countries. This issue of global prices may also be fully integrated with the product designing process, which is an approach commonly used, for example, by Japanese companies. Prices in global markets must be reviewed in regular time intervals, and, when necessary, adjusted, namely adapted to the conditions of a specific foreign market. Pricing strategies may vary depending on a product's life cycle stage and the competitive situation in each country. The pricing strategy in each of the foreign markets where a company runs their business should take into consideration the bottom price limit, the upper price limit, and the optimal prices. The price decisions are also limited by the activities of competitors. If they manufacture/supply in a country with lower costs, it may be necessary to reduce prices to stay competitive. An important aspect related to the pricing policy implemented by enterprises is the issue of the relationship between the quality and the price. Still, numerous international studies have demonstrated that a weak relationship exists between the price and the quality. The authors have concluded that the absence of a strong relationship between the price and the quality seems to be an international phenomenon. Consumers who know little about the quality of a product rely more on the product appearance and less on the so-called technical quality measured by various kinds of testing organizations. Still, some researchers claim that this relationship is strong and of great importance for the product value. Clients' knowledge regarding the technology of a new product on international markets and their awareness in this respect may play an important role in pricing. Owing to the fact that the manufacturer's knowledge regarding the product differs from that of consumers, the clients' knowledge is simply limited, the producer can use this in order to obtain a better bonus from a specific foreign market (Snieskiene \& Cibinskiene, 2015, pp. 92-98; We \& Zhao, 2014, pp. 258-278; Diamantopoulos, 1995).

The pricing strategy based on skimming is an attempt to reach such a market segment that is willing to pay a higher price for a product. In such a case, the product must either create a high value for the buyers or the clients' knowledge about, e.g., the technology applied in the product must be insufficient (Hollensen, 2017, pp. 540, 545). This pricing strategy is often used at the initial stage of a product's life cycle, when both the production capacity and the competition are still limited by fixing a high price, and the demand is limited to people who are ready and able to pay the price proposed. The purpose of the above pricing policy is to maximize the revenues from a limited sales volume for the purpose of satisfying the demand and strengthening the clients' perception of a high value product (Hinterhuber \& Liozu, 2019, pp. 15-23). Penetration pricing in international marketing uses the price as a competitive weapon in order to achieve a market position. Low labor costs benefit such companies and their pricing policy. Usually, exporters who begin operating on foreign markets, having therefore little experience, do not apply this type of prices due to the risk of certain losses at the initial stage that are not affordable for a beginner export company (Meehan, Simonetto, Montan, \& Goodin, 2011, pp. 38-41). Some innovative companies, when their product is not suitable for patenting, use this strategy to ensure the saturation of the market before other competitors manage to do the same (Mansour, 2020). The sales volume that an exporter expects to achieve on the markets leads to the economies of scale and lower costs. The strategies of price leaders are applied by those enterprises that strive to keep their market share. In domestic marketing, this strategy often consists simply in responding to the prices introduced by competitors and corresponding compensation of the pricing policy. One strategy, often applied by SMEs which only start their export operations, is the passive "costplus" reasonable margin strategy, namely a price determined by adding a specified mark-up to the production cost. Its purpose is to achieve a share in the export market. The cost-plus method requires summing up all the costs necessary to deliver a product to the destination, including also shipment costs and additional fees, and the profit expected by the manufacturer. This approach ignores, however, the demand and the competition in the target market (Kotabe \& Helsen, 2016, pp. 383-384). However, in the light of insufficient knowl- 
edge regarding the competition functioning in each market, this approach may be often burdened with an overestimation or underestimation error. Still, new exporters do not care about that since they only react to market opportunities and look for them actively. Still, over a longer period, exporters must calculate additional costs. In order to reduce the risk, beginner exporters perform calculations which take account of, e.g., the CIF price, which leads to a higher price, since the costs in the form of customs duties, international transport, insurance policies grow because the seller is under the obligation to insure their product for the minimum coverage of the risks, transaction financing, the distributor's margin, etc. Thus, the price growth may escalate (Hollensen, 2017, p. 537). The question arises what to do to stay competitive on a foreign market. There are several options of solving the above-described price escalation issue. Domestic manufacturers may be forced to switch to lower wages in countries where they buy certain components or even finished products in order to maintain cost competitiveness. Low wages are an advantage, but only in the short run, as noted by Obadiaa and Stöttinger, over a longer period, innovations and innovativeness determine one's competitive advantage. Another option is buying finished products abroad, near local markets. A manufacturer can conclude one of agreements such as a license or a joint venture. In this case, the manufacturer is present on the market, and high costs, e.g., associated with transport within the country, will not be a problem. Another option is proper rationalization of the distribution structure, which may significantly reduce the total costs associated with the distribution on the international market (Obadiaa \& Stöttinger, 2015, pp. 311-318). This modification of distribution channels can include choosing new intermediaries, assigning new duties to old intermediaries, or establishing actions related to direct marketing. Exporters also face dumping, which consists in selling products imported at a price lower than the one normally applied on the domestic market or in the country of origin. Numerous countries have their own anti-dumping policy, but the key problem is proving that a given company applies prohibited practices (Kotabe \& Helsen, 2016, pp. 384-385). To sum up, the pricing strate- gies being implemented play a crucial role in the purchasing behaviors of consumers and in the process of making decisions on international markets where pricing is one of the most important elements in the mix marketing of SMEs and determines their survival on export markets.

\section{Methodology}

The study presented was conducted between May - June 2019 on a representative sample of Polish SMEs created after 2004: non-exporters and exporters with at least $25 \%$ share of exports in the total sales. The research method applied is computer assisted web interviewing (CAWI) and computer assisted telephone interviewing (CATI). The total count of the sample is 240 businesses, randomly selected from a database which contains 2969 Polish companies. The study covers 240 commercial entities in Poland, half of which $(\mathrm{n}=120)$ have never exported their products. The other portion of the enterprises is currently exporting, most often for more than 3 years $(\mathrm{n}=87)$, the share of the groups exporting for between $1-3$ years $(n=13)$ and up to 1 year $(n=19)$ is much smaller.

The group which has achieved 25 percent of the total sales in the exporting enterprises share in up to 3 years includes $34.17 \%$ of the exporting enterprises $(n=41)$, the remaining $65.83 \%$ of the exporting enterprises have reached the share of 25 percent in the total sales from exports in more than 3 years $(n=79)$. The results were analyzed in the SPSS software, and the qualitative data is presented as the number $(\mathrm{N})$ and the percentage size of each group (\%). Pearson's chi-squared tests were used in the statistical analysis. The differences between the groups were considered significant when the value of $p<0.05$ for the statistical test performed. The correlations between the ordinal variables were verified by means of Spearman's rank correlation.

\section{Results and Discussion}

\subsection{Research Hypotheses}

The following research hypotheses are verified:

H1. There are differences between exporting companies and non-exporting companies in the application of pricing strategies. 
Exporting enterprises more frequently have a differentiated pricing policy.

H2. In the case of companies which are exporters, the exporting time has no impact on the pricing policy and the product quality policy applied.

H3. A significant relationship between the pricing strategy and the quality strategy is visible, both in non-exporting enterprises and in intense exporters.

H4. There is a significant relationship between the pricing policy of companies running a differentiated pricing policy and the product quality. Companies having products of a quality higher than those of the competitors have also higher prices than the competitors.

\subsection{Comparison Between Exporters and Non-Exporters}

Table 1 includes a comparison intended to determine whether or not there is any similarity between exporting companies and non-exporters with regard to the application of pricing strategies. The obtained results indicate the occurrence of significant differences for the entities analyzed. Exporters more often run differentiated pricing policy $-77.50 \%$ compared to $54.17 \%$ of non-exporters. The obtained difference of about $23 \%$ is significant, where the value $\mathrm{p}<0.001$, for Pearson's chi-squared test.

Table 1. Comparison of the answers and statistical analysis of the results of applying a uniform pricing strategy by exporting companies and by non-exporting companies

\begin{tabular}{|c|c|c|c|c|c|c|}
\hline \multirow{2}{*}{ Response } & \multicolumn{2}{|c|}{ Exporters } & \multicolumn{2}{|c|}{ Non-exporters } & \multirow{2}{*}{ Test result } & \multirow{2}{*}{ P value } \\
\cline { 2 - 5 } & N & $\%$ & N & $\%$ & & \\
\hline \multicolumn{7}{|c|}{ Applying a uniform price policy } \\
\hline uniform price policy & 27 & $22.50 \%$ & 55 & $45.83 \%$ & \multirow{2}{*}{14.523} & $<0.001$ \\
\hline diversified price policy & 93 & $77.50 \%$ & 65 & $54.17 \%$ & & \\
\hline
\end{tabular}

Source: author's own study.

The results regarding the responses of the entities surveyed (exporting and nonexporting companies) with regard to the pricing policy that they apply demonstrate similar results for both groups. In both groups, the most common responses indicated that prices are compared with the average prices in the market $(65.83 \%$ for the exporting group and $69.17 \%$ for the non-exporting group).

Among the companies running a uniform pricing policy, the statistical analysis demonstrated no statistically significant differences in prices between exporting companies and non-exporters $(p=0.595)$ (see Table 2).

Table 2. Amount of prices with breakdown into research groups, companies running uniform pricing policy

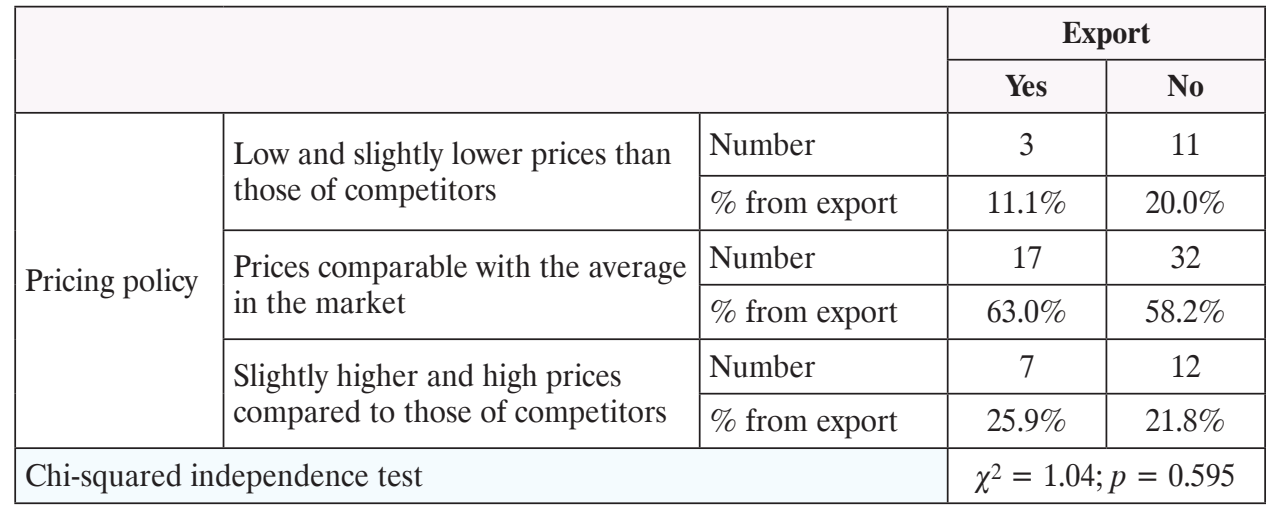

Source: author's own study. 
Among the companies running a differentiated pricing policy, the statistical analysis demonstrated no statistically significant differences in prices between exporting companies and non-exporters $(p=0.308)$ (see Table 3).

Table 3. Amount of prices with breakdown into research groups, companies running a differentiated pricing policy (the price of the most of assortment)

\begin{tabular}{|c|c|c|c|c|}
\hline & & & & \\
\hline & & & Yes & No \\
\hline & Low and slightly lower prices than & Number & 15 & 13 \\
\hline & those of competitors & $\%$ from export & $16.1 \%$ & $20.0 \%$ \\
\hline Pricino policy & Prices comparable with the average & Number & 51 & 40 \\
\hline & in the market & $\%$ from export & $54.8 \%$ & $61.5 \%$ \\
\hline & Slightly higher and high prices & Number & 27 & 12 \\
\hline & compared to those of competitors & $\%$ from export & $29.0 \%$ & $18.5 \%$ \\
\hline Chi square in & pendence test & & $\chi^{2}=2.3$ & $=0.308$ \\
\hline
\end{tabular}

Source: author's own study.

\subsection{Strategies With Regard to the Application of Quality Policy}

The responses with regard to the application of the quality policy by both groups of enterprises demonstrated that in both cases the most common responses indicated high quality as compared to competitors $(45.83 \%$ for exporters and $42.50 \%$ for non-exporters) and that the companies offer slightly higher quality when compared to that of the competitors $(31.67 \%$ and $39.15 \%)$.
The statistical analysis did not demonstrate that the quality policy for products differs to a significant extent between export-oriented companies and non-exporters $(p=0.371)$. Among the exporting companies, the application of a differing quality policy was demonstrated by $17.50 \%$ of the examined entities, and for non-exporters it is $13.33 \%$ of the companies surveyed (see Table 4).

Table 4. Quality policy for products with breakdown into research groups

\begin{tabular}{|c|c|c|c|c|}
\hline & & & \multicolumn{2}{|c|}{ Export } \\
\hline & & & Yes & No \\
\hline \multirow{4}{*}{$\begin{array}{l}\text { The quality } \\
\text { policy for } \\
\text { products }\end{array}$} & \multirow{2}{*}{$\begin{array}{l}\text { The quality of all our products is at } \\
\text { the same level }\end{array}$} & Number & 99 & 104 \\
\hline & & $\%$ from export & $82.5 \%$ & $86.7 \%$ \\
\hline & \multirow{2}{*}{$\begin{array}{l}\text { The quality of our products varies } \\
\text { depending on, e.g., the market and } \\
\text { the type of buyers }\end{array}$} & Number & 21 & 16 \\
\hline & & $\%$ from export & $17.5 \%$ & $13.3 \%$ \\
\hline \multicolumn{3}{|c|}{ Chi-squared independence test } & \multicolumn{2}{|c|}{$\chi^{2}=0.80 ; p=0.371$} \\
\hline
\end{tabular}

Source: author's own study. 
Among the companies having products at the same level, the statistical analysis demonstrated no statistically significant dif- ferences in the quality of products between exporters and non-exporters $(p=0.203)$ (see Table 5).

Table 5. Quality of products with breakdown into research groups, companies having products at the same level

\begin{tabular}{|c|c|c|c|c|}
\hline & & & \multicolumn{2}{|c|}{ Export } \\
\hline & & & Yes & No \\
\hline \multirow{6}{*}{$\begin{array}{l}\text { Product } \\
\text { quality }\end{array}$} & \multirow{2}{*}{$\begin{array}{l}\text { Low and slightly lower quality } \\
\text { when compared to that of the } \\
\text { competitors }\end{array}$} & Number & 2 & 1 \\
\hline & & $\%$ from export & $2.0 \%$ & $1.0 \%$ \\
\hline & \multirow{2}{*}{ Average quality in the market } & Number & 16 & 27 \\
\hline & & $\%$ from export & $16.2 \%$ & $26.0 \%$ \\
\hline & \multirow{2}{*}{$\begin{array}{l}\text { Slightly higher and higher quality } \\
\text { when compared to that of the } \\
\text { competitors }\end{array}$} & Number & 81 & 76 \\
\hline & & $\%$ from export & $81.8 \%$ & $73.1 \%$ \\
\hline \multicolumn{3}{|c|}{ Chi-squared independence test } & \multicolumn{2}{|c|}{$\chi^{2}=3.19 ; p=0.203$} \\
\hline
\end{tabular}

Source: author's own study.

Among the companies having products matched to the market and the buyers, the statistical analysis demonstrated no statisti- cally significant differences in the quality of products between exporters and nonexporters $(p=0.211)$ (see Table 6$)$.

Table 6. Quality of products with breakdown into research groups, companies having products matched to the market and the buyers (the quality of most of the assortment)

\begin{tabular}{|c|c|c|c|c|}
\hline & & & \multicolumn{2}{|c|}{ Export } \\
\hline & & & Yes & No \\
\hline \multirow{4}{*}{$\begin{array}{l}\text { Product } \\
\text { quality }\end{array}$} & \multirow{2}{*}{ Average quality in the market } & Number & 4 & 6 \\
\hline & & $\%$ from export & $19.0 \%$ & $37.5 \%$ \\
\hline & \multirow{2}{*}{$\begin{array}{l}\text { Slightly higher and higher quality } \\
\text { when compared to that of the } \\
\text { competitors }\end{array}$} & Number & 17 & 10 \\
\hline & & $\%$ from export & $81.0 \%$ & $62.5 \%$ \\
\hline \multicolumn{3}{|c|}{ Chi-squared independence test } & \multicolumn{2}{|c|}{$\chi^{2}=1.57 ; p=0.211$} \\
\hline
\end{tabular}

Source: author's own study.

\subsection{Pricing Policy vs Product Quality}

The correlation analysis demonstrated no statistically significant connection between the pricing policy of the companies running a uniform pricing policy and the product quality among the companies having products at the same level $(p=0.170)$ and the product quality in the companies having a diversified quality level of products $(p=0.322)$ (see Table 7). 
Table 7. Spearman's rank correlation values. The association between the price strategy of the companies running a uniform pricing policy and product quality

\begin{tabular}{|l|l|c|}
\hline \multicolumn{2}{|c|}{} & Pricing policy \\
\hline \multirow{2}{*}{ Product quality - (the same level) } & Correlation coefficient & 0.16 \\
\cline { 2 - 3 } & Significance (bilateral) & 0.178 \\
\hline \multirow{2}{*}{ Product quality - (diversified level) } & Correlation coefficient & 0.44 \\
\cline { 2 - 3 } & Significance (bilateral) & 0.322 \\
\hline
\end{tabular}

Source: author's own study.

The correlation analysis demonstrated a statistically significant relationship between the pricing policy of the companies running a differentiated pricing policy and the product quality among the companies having products at the same level $(p<0.001)$ and the product quality in the companies having a diversified quality level of products $(p=0.001)$. The companies having products of a quality higher than those of the competitors had also higher prices than the competitors (see Table 8).

Table 8. Spearman's rank correlation values. Association between the price strategy of the companies running a differentiated pricing policy and product quality

\begin{tabular}{|l|l|c|}
\hline \multicolumn{2}{|c|}{} & Pricing policy \\
\hline \multirow{2}{*}{ Product quality - (the same level) } & Correlation coefficient & 0.31 \\
\cline { 2 - 3 } & Significance (bilateral) & $<0.001$ \\
\hline \multirow{2}{*}{ Product quality - (diversified level) } & Correlation coefficient & 0.58 \\
\cline { 2 - 3 } & Significance (bilateral) & 0.001 \\
\hline
\end{tabular}

Source: author's own study.

An analogous analysis performed to evaluate the quality policy between the entities being surveyed does not indicate significant differences.

\subsection{Comparison Between Entities Exporting for Short and for Longer Periods of Time}

The following are statistical analyses with regard to whether the exporting time affects the pricing policy and the quality policy applied in the case of the companies which are exporters.

The results presented in Table 9 apply to comparing the results regarding price policies. The results obtained indicate that $73.17 \%$ of the companies exporting for up to 3 years apply a differentiated pricing policy, and within the group exporting for more than 3 years this result is $79.75 \%$. The value $p=0.413$, meaning that the groups being compared do not differ significantly.

Table 9. Comparison of the answers and statistical analysis of the results of applying a uniform price policy by companies exporting for up to 3 years and those exporting for over 3 years

\begin{tabular}{|l|c|c|c|c|c|c|}
\hline \multirow{2}{*}{ Response } & \multicolumn{2}{|c|}{ Up to 3 years } & \multicolumn{2}{|c|}{ More than 3 years } & \multirow{2}{*}{ Test result } & \multirow{2}{*}{ P value } \\
\cline { 2 - 5 } & $\mathbf{N}$ & $\%$ & N & \% & \\
\hline Applying a uniform price policy \\
\hline uniform price policy & 11 & $26.83 \%$ & 16 & $20.25 \%$ & \multirow{2}{*}{0.669} & \multirow{2}{*}{0.413} \\
\hline diversified price policy & 30 & $73.17 \%$ & 63 & $79.75 \%$ & & \\
\hline
\end{tabular}

Source: author's own study. 
As in the case of the price policy, also the quality policy does not vary between the companies exporting for short and long periods. The obtained results indicate that $14.63 \%$ of the companies exporting for up to 3 years apply a differentiated quality policy, and within the group exporting for more than 3 years this result is $18.99 \%$. The value $\mathrm{p}=0.552$, meaning that the groups being compared do not differ significantly. The results have been included in Table 10.

Table 10. Comparison of the answers and statistical analysis of the results of applying a uniform quality policy for products by companies exporting for up to 3 years and those exporting for over 3 years

\begin{tabular}{|c|c|c|c|c|c|c|}
\hline \multirow{2}{*}{ Response } & \multicolumn{2}{|c|}{ Up to 3 years } & \multicolumn{2}{|c|}{ More than 3 years } & \multirow{2}{*}{$\begin{array}{l}\text { Test } \\
\text { result }\end{array}$} & \multirow{2}{*}{$P$ value } \\
\hline & $\mathbf{N}$ & $\%$ & $\mathbf{N}$ & $\%$ & & \\
\hline \multicolumn{7}{|c|}{ Applying a uniform product quality policy } \\
\hline $\begin{array}{l}\text { The quality of all products } \\
\text { is at the same level }\end{array}$ & 35 & $85.37 \%$ & 64 & $81.01 \%$ & \multirow[b]{2}{*}{0.354} & \multirow[b]{2}{*}{0.552} \\
\hline $\begin{array}{l}\text { The product quality varies } \\
\text { depending on the market, } \\
\text { and the type of buyers }\end{array}$ & 6 & $14.63 \%$ & 15 & $18.99 \%$ & & \\
\hline
\end{tabular}

Source: author's own study.

\section{Conclusions}

The development of a pricing strategy is an important task in marketing, since prices are its only element which generates profits/revenues; other components create only costs. Thus, a pricing strategy may be considered a fundamental aspect which affects the success of small and mediumsized enterprises. The results support hypotheses $1,2,4$, and there is no evidence confirming the third hypothesis. In connection with the above, it is justified to conduct further comparative studies for small and medium-sized non-exporting enterprises and intense exporters regarding their pricing strategies and the connection between the pricing strategy and the quality strategy among these entities.

\section{Acknowledgement}

The research was supported by the National Science Centre, Poland; project no. 2015/19/B/HS4/01728, and by the statutory research fund of the Collegium of World Economy, Warsaw School of Economics.

\section{References}

Brassington, F., \& Pettitt, S. (2013). Essentials of marketing (3rd ed). Harlow: Pearson.

Carpenter, B.W., Boyle, D.M., \& Ren, Y. (2012). The impending demise of LIFO: History, threats, implications, and potential remedies. The Journal of Applied Business Research, 28(4), July/August.

Diamantopoulos, A. (1995). Making pricing decisions: A study of managerial practice. London: Chapman and Hall.

Diller, H., \& Bukhari, I. (1994). Pricing conditions in the European common market. European Management Journal, 12(2).

Dolgui, A., \& Proth, J.M. (2010). Pricing strategies and models. Annual Reviews in Control, 34.

Doole, I., \& Lowe, R. (2016). International marketing strategy. Cengage Learning.

Du, J., \& Li, M. (2019). The pricing mechanism and decision-making of core components based on the game model under the implicit condition of localization substitution. In 2019 Chinese Control And Decision Conference (CCDC) Proceedings. Retrieved from https://ieeexplore.ieee.org/xpl/conhome/8822348/proceeding.

Gherasim, D., \& Gherasim, A. (2019). Strategies regarding prices within the international marketing. Economy Transdisciplinarity Cognition, 22(1). 
Gorodnichenko, Y., \& Talavera, O. (2017). Price setting in online markets: Basic facts, international comparisons, and cross-border integration. The American Economic Review, 107(1).

Gullstrand, J., Olofsdotter, K., \& Thede, S. (2014). Markups and export-pricing strategies. Review of World Economics, 150(2).

Hinterhuber, A., \& Liozu, S.A. (2019). Pricing strategy implementation. Translating pricing strategy into results. New York: Routledge.

Hofer, K.M., Niehoff-Hoeckner, L.M., \& Totzek, D. (2019). Organizing and implementing export pricing: Performance effects and moderating factors. Journal of International Marketing, 27(1).

Hollensen, S. (2017). Global marketing (7th ed.). Harlow: Financial Times Prentice Hall.

Jain, S.C. (1989, January). Standardization of international marketing strategy: Some research hypotheses. Journal of Marketing, 53.

Kotabe, M., \& Helsen, K. (2016). Global marketing management ( 7 th ed.).

Mansour, M. (2020, January), The moderating role of innovation intensity between international marketing strategy and international marketing performance: Branding and commitment in international marketing. International Journal of Business Innovation and Research, 1(1).

Meehan, J., Simonetto, M., Montanm L., \& Goodin, C. (2011). Pricing and profitability management: A practical guide for business leaders. Singapore: John Wiley \& Sons.
Monroe, K., \& Lee, A.Y. (1999). Remembering versus knowing: Issues in buyers' processing of price information. Journal of the Academy of Marketing Science, 27(2).

Neubert, M. (2017). International pricing strategies for born-global firms. Central European Business Review, 6(3).

Obadiaa, C., \& Stöttinger, B. (2015, April). Pricing to manage export channel relationships. International Business Review, 24(2).

Porter, M.E. (1985). Competitive strategy: Techniques for analyzing industries and competitors. New York: Free Press.

Sikora, T., \& Baranowska-Prokop, E. (2021). The role of strategic agility and economic environment's friendliness-hostility in explaining success of Polish SMEs. In N. Tsounis \& A. Vlachvei (Eds.), Advances in longitudinal data methods in applied economic research. ICOAE 2020 (Springer Proceedings in Business and Economics). Cham: Springer.

Snieskiene, G., \& Cibinskiene, A. (2015). Export price: How to make it more competitive. ProcediaSocial and Behavioral Sciences, 213, 92-98.

Wei, J., \& Zhao, J. (2014). Pricing and remanufacturing decisions in two competing supply chains. International Journal of Production Research, 53(1).

Whitelock, J., \& Pimblett, C. (1997). The standardization debate in international marketing. Journal of Global Marketing, 10(3). 